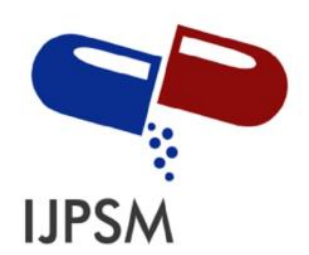

Amruthavalli G.V et al, Int. Journal of Pharmaceutical Sciences and Medicine (IJPSM),

Vol.6 Issue. 3, March- 2021, pg. 76-84

ISSN: 2519-9889

Impact Factor: 3.426

\title{
The Possible Interaction of Mahanarayana Thaila with Inflammatory Mediators and Associated Blood Flow in Response to Photon Emission
}

\author{
Amruthavalli G.V*; Aruna.V; Gayathri.R \\ Dr. JRK's Research and Pharmaceuticals Pvt Ltd, No.18 \& 19, Perumal koil street, Kunrathur, Chennai-600069. \\ amruthavalli_gv@jrkresearch.com; research@jrkresearch.com \\ Author Details: \\ Amruthavalli G.V: Asst. Manager-Research and Pharmaceuticals Pvt ltd, amruthavalli_gv@jrkresearch.com, \\ 9940327847 \\ Aruna V: Manager-Quality control \& Production, aruna_v@jrkresearch.com, 9566165310 \\ Gayathri R: Director, gayathri_rajagopal@jrkresearch.com, 9841027502 \\ DOI: 10.47760/ijpsm.2021.v06i03.007
}

\begin{abstract}
Mahanaraya thaila is a well-known Sastric Ayurveda drug for pain relief. It is a polyherbal formulation. In the present study the JRK's Mahanarayana thaila is compared with other market samples for its efficacy, purity and particulate matter. Sub epidermal blood flow around photon emission zone, miscible components and acid value test are conducted for JRK's Mahanaraya thaila and other market samples. Results shows that the JRK's Mahanarayana thaila is having greater efficacy due to miscible actives and low acid values of the finished product compared to other market samples. Complete details are presented in the paper.
\end{abstract}

\section{Keywords,}

Ayurveda for pain relief, Mahanarayan taila, JRK's oil, massage oil for pain 


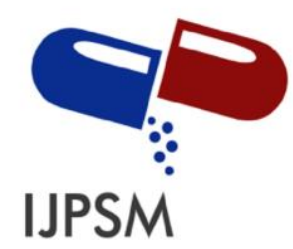

Amruthavalli G.V et al, Int. Journal of Pharmaceutical Sciences and Medicine (IJPSM), Vol.6 Issue. 3, March- 2021, pg. 76-84

ISSN: 2519-9889

Impact Factor: $\mathbf{3 . 4 2 6}$

\section{Introduction:}

Since time immemorial, human beings were suffering from various ailments and among them, pain which is medically referred as ache has been agonizing human life. In order to alleviate humanity from various forms of aliments, the medical science of today thus got evolved.

Unlike present day medical science where the diagnostic procedures are established by series of trials and error, experimentation and multi-centric evaluation and so are the drugs used for the treatment, the traditional system of medicine got evolved from the total and complete understanding of the human body and mind relationship his/her habit and habitat, lifestyle, diet, morality and ethics and other positive and negative behavioral traits etc. Hence the traditional system of medicine in India always approach the treatment in a most holistic way where the aberrations within the physical matrix of the body as well as the aberration between the body and mind in toto is considered for both the diagnosis and the treatment.

Management of pain that does not have any obvious injury (degenerative nature) such as joint pain, cervical spondylosis, generalized body pain etc., are treated with massage therapy in traditional system of medicine.

In the process of massage therapy, the Vaidya who administers massage constantly interact with the patient and thereby customize the massage therapy that is required for the given patient to experience relief. Such treatment is called highly patient centric, customized therapy. Whereas, allopathic system largely employs generalized therapy wherever the treatment is limited with drugs (except surgical intervention). The recipe used for massage therapy in the case of Ayurveda and Siddha were well standardized by the spiritual scholars of the above systems through the above matrix of spiritual philosophy.

Mahanarayana thaila is one such Ayurveda preparation used for treating pain. ${ }^{1,2,3}$ The thaila concoction is comprised of the following herbs, Bilva (Aegle marmelos),Asvagandha mula (Withania somnifera), Brhati mula (Solanum indicum),Swadamstra (Tribulus terrestris),Syonaka mula (Oroxylum indicum), Vatyalaka ( Sida cordifolia),Paribhadra mula (Erythrina indica), Kantakari mula (Solanum xanthocarpum), Kathilla (Boerhaavia diffusa),Prasarni mula (Paederia foetida),Atibala (Abutilon indicum),Agnimantha (Clerodendrum phlomidis),Patali mula (Sterospermum suaveolens), Goksheera (Cow's milk),Sesame oil (Sesame indicum),Juice of satavari (Asparagus racemosus), Rasna (Pulchea lanceolata),Asvagandha mula (Withania somnifera),Misi(Sathava) (Anethum sowa),Devadaru (Cedrus deodara) ,Kustha ( Saussurea lappa),Salaparni (Desmodium gangeticum),Prsniparni (Uracia picta),Mudgaparni ( Phaseolus trilobus), Masaparni (Termnus labialis),Agaru ( Aquilaria agallocha),Nagakesara (Mesua ferrea),Saindhava (Rock salt),Mamsi (Nardostachys jatamansi), Haridra (Curcuma longa),Daruharidra (Berberis aristata),Saileyaka (Parmeila peralta),Candana (Santalum album),Puskara (Inula racemosa), Ela (Elettaria cardamomum),Manjistha (Rubia cordifolia),Yasti 


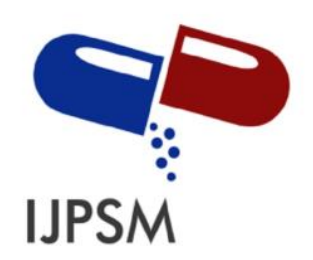

Amruthavalli G.V et al, Int. Journal of Pharmaceutical Sciences and Medicine (IJPSM), Vol.6 Issue. 3, March- 2021, pg. 76-84

ISSN: 2519-9889

Impact Factor: 3.426

(Glycyrrhiza glabra),Tagara (Valeriana wallichi),Abda (Cyperus rotundus), Tejapatra (Cinnamomum tamala),Bhrngaraja( Eclipta alba),Jivaka (Malaxis acuminate), Rsabhaka (Malaxis muscifera),Meda (Polygonatum verticillatum),Mahameda ( Polygonatum cirrhifolium),Kakoli (Lilium polyphyllum),Ksira kakoli (Fritillaria roylei),Rduki(Riddhi) (Habenaria intermedia),Vrddhi ( Habenaria edeworthi),Ambu (Pavonia odorata), Vaca (Acorus calamus),Palasa (Butea monosperma), Sthauneya (Taxus baccata) ,Vrsciratha (Boerhavia erecta), Corak (Angelica glauca), Karpura (Cinnamomum camphora), Kesara ( Crocus sativus), Kasthuri (Musk).

All the herbs used in the concoction are carefully analyzed and tested by our ancient Ayurveda scholars with their extra-terrestrial intuition and divine wisdom. From the spiritual parlance if we look, all the Ayurveda and Siddha drugs have great divine touch, although may lack scientific touch of the modern day science. However, the divine wisdom is superior over scientific wisdom because the scientific wisdom always limits itself in the laboratory evidence and the findings are dismissed outrageously or accepted in total based on the findings.

Dr.JRK's Research and Pharmaceuticals Pvt Ltd is the research based company to champion the cause of traditional school of healing practices. The company has brought out several scientific facts and expressions that were hidden in various siddha and Ayurveda drugs and have achieved several laurels and glories to Ayurveda and Siddha from global community.

In order to establish the science behind the therapeutic benefit of Mahanaraya Thaila the present study was done. We have established further how Mahanarayana thaila increases the dilution and distribution of inflammatory agents and enhances the peripheral blood flow to reduce pain.

We have used an advanced technology where the reflection of the blood at sub epidermal level due to treatment intervention was recorded with the help of continuous photon emission. This is the first study to best of our knowledge establishes the therapeutic value and undisputable science behind Mahanarayana thaila. Details are presented in the paper.

\section{Materials and Methods}

\section{Treatment of Mahanarayan thailam in human volunteers}

Mahanarayana thailam of Dr.JRK's and the same brand manufactured by competitor company were used for the study.

Twenty healthy volunteers were consented for the study. The volar forearm region of both right and left arm were chosen for the study. $2 \mathrm{ml}$ of the oil was applied over the pre designated volar forearm region and massaged gently for 2 minutes. After 2 minutes the massage therapy was withdrawn and treated site was left untreated for further 5 minutes. After 5 minutes' photon emitting device was used to 


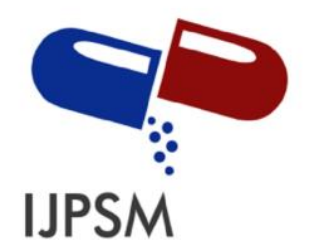

Amruthavalli G.V et al, Int. Journal of Pharmaceutical Sciences and Medicine (IJPSM), Vol.6 Issue. 3, March- 2021, pg. 76-84

ISSN: 2519-9889

Impact Factor: 3.426

measure the sub epidermal blood flow based on the reflectance response for photon emission. The extent of reflectance and doplometric dermal changes were photo documented and scored numerically and the response in the sub epidermal region before and after treatment was compared. Similarly, the treatment response to JRK's Mahanarayana thaila and competitor brand were also compared.

\section{Acid value test}

Accurately weigh $10 \mathrm{gm}$ of sample into a $250 \mathrm{ml}$ flask, and add $50 \mathrm{ml}$ of a mixture of equal volumes of ethanol and ether, which is neutralized with $0.1 \mathrm{M}$ potassium hydroxide after the addition of few drops of phenolphthalein as an indicator. Titrate the solution until it turns to pink colour and persists for 15 sec. Note the number of $\mathrm{ml}$ required to neutralize the solution. Perform blank simultaneously. Calculate the acid value from the following formula:

[? ]Acid value $=($ Titre value- blank $) \times \mathrm{N} \mathrm{KOH} \times 56.1 /$ Weight of sample taken gm

Determination of \% of methanol soluble constituents from Mahanarayana thaila:

$10 \mathrm{gm}$ of sample was taken and then extracted with methanol. The methanol fraction was collected and evaporated to dryness. The weight was noted.

\section{Determination of the fineness of herbal particles in methanol fraction after filtration:}

$10 \mathrm{gm}$ of sample was taken and then extracted with methanol. The methanol fraction was collected and filtered through Whattman No.1. the filtrate was evaporated to dryness. The weight was noted.

\section{Miscibility of herbal constituents Vis-a -vis acid values ( $1 \%$ herbal extract is used in gingelly oil)}

Gingelly oil was taken and then it was artificially induced to increase its acid value to 5, 10, 15, 20 and 25 respectively. And then $1 \%$ extract of all herbs used in Mahanarayana thaila was incorporated in the oils stirred for 2 hours and then allowed to stand for further 5 hours. After 5 hours $20 \mathrm{ml}$ of oil was collected into a separate beaker without disturbing the sedimented extracts at the bottom. To the oil a known volume of methanol was added and then the methanolic fraction was divided into two portions. One portion was used for calculating the total extractable matter. For the above purpose, the solvent was allowed to evaporate completely and after removal of solvent the weight of the extract thus settled was used for calculating the \% of total extract. The other portion of the methanolic fraction was filtered through Whattman No.1 then the filtrate was dried to evaporate the methanol in a pre-weighed crucible and then the weight of the extract was determined and percentage of sub-microscopic extract was calculated. 


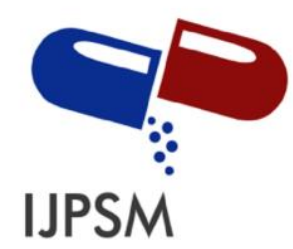

Amruthavalli G.V et al, Int. Journal of Pharmaceutical Sciences and Medicine (IJPSM), Vol.6 Issue. 3, March- 2021, pg. 76-84

ISSN: 2519-9889

Impact Factor: 3.426

\section{Results:}

The photon emittance device was gently pressed over the treatment site and the reflectance was recorded. ${ }^{4}$ Dr.JRK's Mahanarayana thaila has resulted in $13 \mathrm{~mm}$ increased blood flow around the region where the oil was applied. Whereas in the control (before treatment) the reflectance was only $3 \mathrm{~mm}$ outside the area of photon emittance.

In the case of competitor brand (all four brands) the difference in reflectance value between control and treatment were 3.2 and $5 \mathrm{~mm}$ suggesting that the Mahanarayana thaila of competitor has produced only limited peripheral blood flow at sub epidermal level. (Table 1 and images 1-2)

Table 1:

\begin{tabular}{|c|c|c|c|}
\hline \multirow{2}{*}{ S.No } & \multicolumn{2}{|c|}{ Brand name } & \multicolumn{2}{c|}{$\begin{array}{c}\text { Sub epidermal blood flow around photon } \\
\text { emission zone (in mm) }\end{array}$} \\
\cline { 3 - 4 } & & Before & After \\
\hline 1 & Mahanarayana thaila (Dr.JRK's) & 2.9 & 13.1 \\
\hline 2 & Mahanarayana thaila (Market sample 1) & 3.2 & 4.5 \\
\hline 3 & Mahanarayana thaila (Market sample 2) & 2.3 & 4.6 \\
\hline 4 & Mahanarayana thaila (Market sample 3) & 2.8 & 3.9 \\
\hline 5 & Mahanarayana thaila (Market sample 4) & 3.1 & 4.9 \\
\hline
\end{tabular}

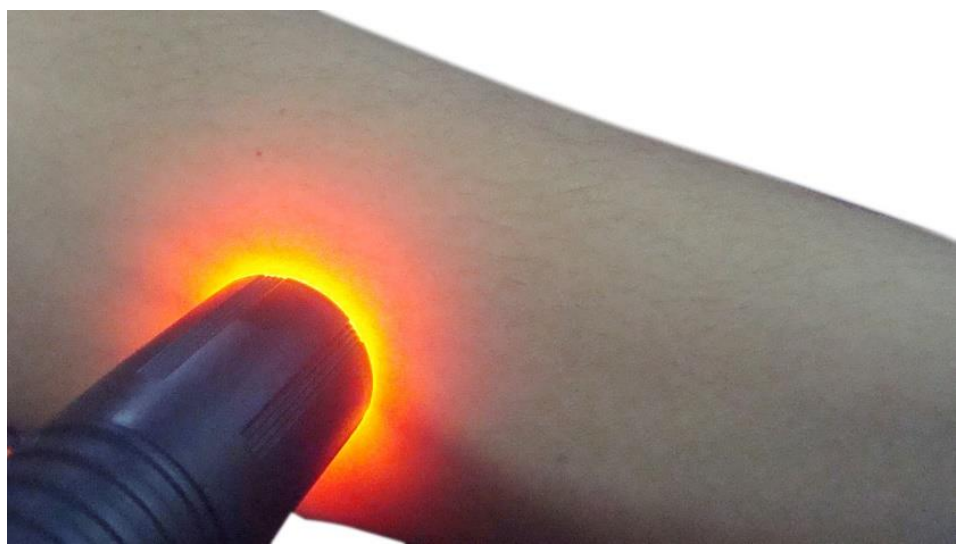

Control (Before treatment)

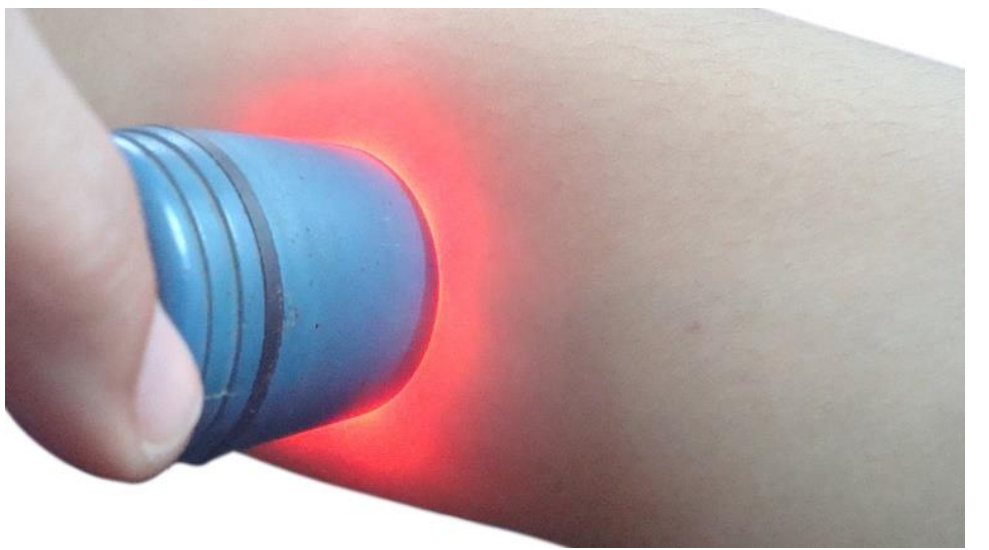

After treatment 


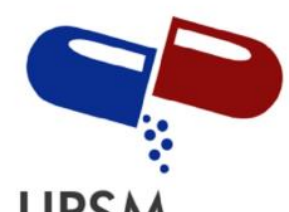

Amruthavalli G.V et al, Int. Journal of Pharmaceutical Sciences and Medicine (IJPSM),

Vol.6 Issue. 3, March- 2021, pg. 76-84

ISSN: 2519-9889

Impact Factor: 3.426

\section{Acid value test:}

Among four market samples tested for acid value, the acid value of JRK's Mahanarayana thaila is the lowest with 5.6 and the acid value of other samples were in two digits (Table-2).

Table-2: Acid value of Mahanrayana thaila

\begin{tabular}{|l|l|}
\hline Brand name & Acid value \\
\hline Mahanarayana thaila (Dr.JRK's) & 5.6 \\
\hline Mahanarayana thaila (Market sample 1) & 23.8 \\
\hline Mahanarayana thaila (Market sample 2) & 9.9 \\
\hline Mahanarayana thaila (Market sample 3) & 11.6 \\
\hline Mahanarayana thaila (Market sample 4) & 17.2 \\
\hline
\end{tabular}

Determination of $\%$ of methanol soluble constituents from Mahanarayana thaila:

The total extractable matter with methanol as solvent of JRK's Mahanarayana thaila is comparable with other market samples (Table-3)

Table -3: \% of Extractable matter

\begin{tabular}{|l|l|}
\hline Brand name & Extractive value \\
\hline Mahanarayana thaila (Dr.JRK's) & 0.07 \\
\hline Mahanarayana thaila (Market sample 1) & 0.1 \\
\hline Mahanarayana thaila (Market sample 2) & 0.09 \\
\hline Mahanarayana thaila (Market sample 3) & 0.09 \\
\hline Mahanarayana thaila (Market sample 4) & 0.08 \\
\hline
\end{tabular}

Determination of extractable matter in methanol after filtration:

JRK's Mahanarayana thaila showed highest extractable matter in the filtrate when compared to other samples suggesting the extractable matter in Mahanarayana thaila is quite fine and possibly absorbable through skin. 


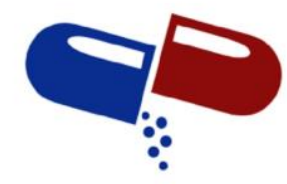

IJPSM

Amruthavalli G.V et al, Int. Journal of Pharmaceutical Sciences and Medicine (IJPSM),

Vol.6 Issue. 3, March- 2021, pg. 76-84

ISSN: 2519-9889

Impact Factor: 3.426

Table-4: \% Extractable matter in filtrate

\begin{tabular}{|l|l|}
\hline Brand name & Extractive value \\
\hline Mahanarayana thaila (Dr.JRK's) & 0.06 \\
\hline Mahanarayana thaila (Market sample 1) & 0.04 \\
\hline Mahanarayana thaila (Market sample 2) & 0.03 \\
\hline Mahanarayana thaila (Market sample 3) & 0.04 \\
\hline Mahanarayana thaila (Market sample 4) & 0.02 \\
\hline
\end{tabular}

Table 5: Miscibility of herbal constituents Vis-a -vis acid values ( $1 \%$ herbal extract is used in gingelly oil)

\begin{tabular}{|c|c|c|}
\hline \multirow{2}{*}{ Acid value } & \multicolumn{2}{|c|}{ \% Extractive value - Methanol fraction } \\
\cline { 2 - 3 } & Total & In the filtrate (After filtration) \\
\hline 5 & 40 & 28 \\
\hline 10 & 15 & 7 \\
\hline 15 & 7 & 2.1 \\
\hline 20 & 3.1 & 1.3 \\
\hline 25 & 1.2 & 0.6 \\
\hline
\end{tabular}

\section{Discussion:}

The present study has clearly positioned the therapeutic superiority of Mahanarayana thaila of Dr.JRK's over other competitor brands. The Photon emittance device has clearly captured how Dr.JRK's Mahanarayana thaila increased the sub epidermal blood flow and which clearly indicates the possibility of dilution and distribution of various inflammatory mediators away from the region of pain thus resulting in instantaneous, long lasting relief.

None of the competitor products of Mahanarayana thaila has increased the peripheral blood flow as significantly as Dr.JRK's mahanarayana thaila which clearly confirms the superior therapeutic value of Dr.JRK's Mahanarayana thaila.

Peripheral blood flow is used as one of the indicators for evaluating the efficacy of topical pain relieving preparations. Increased blood flow usually alleviates pain whereas constriction of blood flow is known to induce pain. 


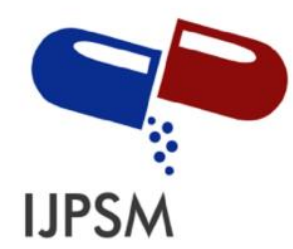

Amruthavalli G.V et al, Int. Journal of Pharmaceutical Sciences and Medicine (IJPSM), Vol.6 Issue. 3, March- 2021, pg. 76-84

ISSN: 2519-9889

Impact Factor: 3.426

The ancient scholars of Siddha and Ayurveda have understood the above science better than the modern day scientists and clinicians and that is why they have brought out several topical preparations for treating pain than oral recipes.

Further the ancient siddha and Ayurveda scholars also have understood the importance of massage therapy in treating pain. Massage therapy coupled with a drug prepared with select herbs would act like a very powerful analgesic drug and that is how Mahanarayana thaila has been formulated.

The therapeutic effect of Mahanarayana thaila is well known and is also globally appreciated and accepted. But still several clinicians offer their confused clinical report over the efficacy of Mahanarayana thaila of different manufacturers. Almost all manufacturers follow more or less the same procedure to manufacture Mahanaryana thaila because the formulation belongs to the traditional healing practices of India or otherwise it is called as classical/sastric preparation. But the question is why Mahanarayana thaila of different manufacturers exhibit different therapeutic benefit lacks clear answer. However, the Mahanaryana thaila of Dr.JRK's is always rated high by Vaidhyas across India and the therapeutic benefit reported is also quite consistent over different batches.

In the present study we have employed both the aspect of efficacy as well as the critical quality parameter. We have used an advanced technology called photon emission device to detect the sub epidermal blood flow. After ascertaining the therapeutic superiority of Dr.JRK's Mahanarayana thaila over market samples, we have also established the quality superiority of the same.

The acid value of JRK's Mahanarayana thaila was the lowest when compared to the market samples. The acid value denotes the quality of the base oil that was used in the formulation. Higher the acid value higher the release of fatty acids and triglycerides in the oil as a result of rancid split and such oil is highly harmful.

For relieving pain not only the recipe should be fast acting and effective, its quality norms also must be superior. Rancidity of the base oil can be minimized only when strict scientific measures are adopted while manufacturing. The lowest acid value of JRK's Mahanarayana thaila also proves how meticulous and disciplined is the manufacturing method adopted by Dr.JRK's Research and Pharmaceuticals in preparing all its products. ${ }^{5}$

We have also established the possible reason for why JRK's Mahanrayana thaila is superior in efficacy than other market samples. For the above purpose we have determined the percentage of herbal constituents at near nano particle size using methanol as solvent. The methanolic fraction of the oil was filtered through whattman No.1 and the herbal constituents in the filtrate was determined. The percentage of herbal constituents at sub-microscopic level in the filtrate prepared from JRK's mahanarayana thaila was higher than that of the competitor products. We presume that the sub 


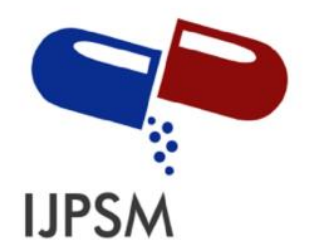

Amruthavalli G.V et al, Int. Journal of Pharmaceutical Sciences and Medicine (IJPSM), Vol.6 Issue. 3, March- 2021, pg. 76-84

ISSN: 2519-9889

Impact Factor: 3.426

microscopic herbal constituents in Mahanarayana thaila of Dr.JRK's coupled with low rancidity value of the oil may be the reason for its superior therapeutic benefit.

In order to establish the link between acid value of the oil and miscibility of herbal extract, we have done a separate experiment. Finally, we have established that the miscibility of herbal extract goes poorer and poorer with increased acid value of the oil. The findings clearly suggest that not only the submicroscopic size of the herbal particles are necessary for superior therapeutics but also their complete miscibility in the oil and which can be adversely affected by the acid value of oil.

Dr.JRK's research and Pharmaceuticals is fully committed for the cause of promoting the sastric drugs globally to alleviate the humanity from various diseases and associated distressed states. Wellness and happiness can be achieved only from the ancient healing practices. The method of manufacturing of various classical preparations by our ancient healing practices are although documented in the scheduled books of Ayurveda and Siddha but the finer and subtle aspects of the manufacturing adopted by ancient healers are seldom decoded or followed by several manufacturers when the commercial end point prevails over preserving the glory of traditional wisdom.

Dr.JRK's research and Pharmaceuticals tries to decode all the divine touches in the manufacturing of various classical preparations of our ancient healing practices and have done intense research. The company is manufacturing all products only as per the latest technology and at the same time preserving the traditional values as well.

Although the present study is limited to Dr.JRK's Mahanarayana thaila but the findings clearly come as an endorsement to all other products of the company with reference to quality and therapeutic superiority. To sum-up, the Mahanrayana thaila is therapeutically effective for relieving pain but a prudent manufacturing SOP's is necessary to achieve the same.

\section{References}

1. Ayurvedic Pharmacopeia of India Part1 second edition, 8: 45 Page. no 436- 439.

2. Vatavyadhi Rogadhikara, Bhaishajya Ratnavali, Chapter 26, Verse: 343 to 354, Page no $151-162$.

3. A Rajendran and R Sudeshraj. The therapeutic value of Ayurvedic proprietary medicine Artin oil for chronic musculoskeletal pain relief \& Arthritis: Review article. The Pharma Innovation Journal 2020; 9(5): 354-358.

4. Farag, Heba E., "A non-invasive method for measuring blood flow rate in superficial veins from a single thermal image." (2013). Electronic Theses and Dissertations. Paper 426. https://doi.org/10.18297/etd/426

5. Aruna v. Amruthavalli et.al., Uniqueness of Dr. JRK's 777 oil and how rancidity distorts Wrightia tinctoria. International Journal of Research in Dermatology 5(3):618; July 2019. 